\title{
Pengaruh Penambahan Isolat Cair Terhadap Karakteristik Kedelai Terfermentasi
}

\section{Effect of Addition of Liquid Isolate on Characteristics of Fermented Soybeans}

\author{
Ni Made Susi Kartika ${ }^{1}$, P Putu Suparthana ${ }^{1 *}$, Luh Putu Trisna Darmayanti ${ }^{1}$ \\ Program Studi Teknologi Pangan, Fakultas Teknologi Pertanian, Universitas Udayana \\ Kampus Bukit Jimbaran, Badung-Bali \\ *Penulis korespondensi: I Putu Suparthana, Email: putusuparthana@unud.ac.id
}

\begin{abstract}
This research aims to determine the effect of adding different amounts of liquid isolate with fermentation time of 24 hours and to obtain the correct addition of liquid isolate to produce fermented soybeans with the best characteristics. Completely Randomized Design (CRD) was used in this research with the addition of liquid isolate treatment consisting of 5 levels namely $1 \%, 2 \%, 3 \%, 4 \%, 5 \%$. Each treatment was repeated 3 times, resultd 15 experimental units. The data were analyzed using the Analysis of Variance (ANOVA) and if the treatment affected the observed variable, it was followed by the Duncan's Multiple Range Test. The results showed that the addition of a liquid isolate had a very significant effect on moisture, ash, protein, fat, carbohydrate, total bacteria content, hedonic test color, aroma, texture and overall acceptance of fermented soybeans. The best characteristics were obtained from the addition of $1 \%$ liquid isolate with the criteria : $18,13 \%$ moisture content $2,39 \%$ ash content, $11,81 \%$ carbohydrate content, total bacteria 9,01log cfu/g, with like color, aroma, texture and overall acceptance.
\end{abstract}

Keywords: soybean, liquid isolate, fermentation, traditional food

\section{PENDAHULUAN}

Kedelai merupakan salah satu komoditas hasil pertanian di Indonesia yang mempunyai potensi besar sebagai sumber utama protein bagi masyarakat. Kedelai telah lama dikenal dan dipakai dalam beragam produk olahan makanan, seperti tempe, tahu, tauco, dan kecap. Salah satu cara pengolahan kedelai adalah difermentasi atau diperam selama satu sampai dua hari. Fermentasi merupakan salah satu proses pengolahan untuk produk pangan dari kedelai, yang mana proses fermentasi diketahui dapat meningkatkan kualitas nilai gizi seperti vitamin dan kelarutan protein pada kedelai (Sohliya et al., 2008).

Produk olahan kedelai yang sudah dikenal oleh masyarakat yang difermentasi menggunakan kapang adalah tempe, selain itu terdapat pula produk fermentasi kedelai di Jepang yang menggunakan bakteri adalah natto. Fermentasi natto dibantu oleh bakteri Bacillus subtilis natto. Natto merupakan salah satu makanan hasil fermentasi yang berasal dari jepang yang berbahan dasar kacang kedelai. Natto secara kasat mata sangat mirip dengan produk fermentasi kedelai yang berasal dari Bali yaitu sere kedele. Pada penelitian yang dilakukan oleh Wei et al.,2001, dilaporkan bahwa karakteristik kedelai fermentasi pada natto, dipengaruhi oleh lama pemasakan, lama fermentasi dan jenis bakteri. Proses fermentasi pada produksi natto memerlukan waktu selam 18 jam menggunakan inokulum B.subtilis natto sebanyak $10^{6}-10^{7} \mathrm{cfu} / \mathrm{g}$ dengan suhu fermentasi $40^{\circ} \mathrm{C}-42^{\circ} \mathrm{C}$. 
Menurut Widyantari et al., (2017) sere kedele saat ini masih diproduksi secara tradisional dengan melibatkan fermentasi secara spontan. Fermentasi kedelai yang dilakukan secara spontan memiliki beberapa kekurangan yakni mutunya tidak stabil dan sangat rendah serta hasilnya tidak seragam (Koesoemawardani et al.,2009). Berdasarkan hal tersebut, untuk memperbaiki proses fermentasi spontan salah satu cara yang dapat dilakukan adalah dengan menggunakan starter. Starter yang digunakan pada pembuatan sere kedele belum ada. Pada penelitian ini dilakukan upaya untuk mendapatkan starter yaitu dengan cara membuat isolat cair yang diambil dari kedelai terfermentasi yang belum ditambahkan bumbu oleh produsen.

Isolat merupakan serangkaian proses pemisahan mikroorganisme supaya didapatkan kultur yang murni. Isolat-isolat tersebut kemudian ditumbuhkan pada medium terpisah supaya dapat tumbuh dengan baik. Medium pertumbuhan bakteri harus tetap terpenuhi sehingga bakteri tidak mengalami kematian. Isolat cair yang digunakan pada penelitian ini telah dipenuhi bakteri dominan yang berperan dalam proses fermentasi kedelai. Namun saat ini belum diketahui berapa penambahan isolat cair untuk menghasilkan kedelai terfermentasi dengan karakteristik terbaik. Berdasarkan hal tersebut, maka perlu dilakukan penelitian penambahan isolat cair dalam jumlah yang tepat untuk menghasilkan kedelai terfermentasi dengan karakteristik terbaik.

\section{METODE PENELITIAN}

\section{Tempat dan Waktu}

Penelitian ini dilaksanakan di Laboratorium Pengolahan Pangan, Analisis Pangan dan Mikrobiologi Pangan Fakultas Teknologi Pertanian, Universitas Udayana, Jalan PB. Sudirman, Denpasar dari bulan Januari 2020 Maret 2020.

\section{Bahan dan Alat}

Bahan yang digunakan dalam pembuatan kedelai terfermentasi adalah kedelai kuning varietas wilis yang diperoleh dari supermarket carrefour, dan isolat dari kedelai terfermentasi yang didapatkan dari salah satu produsen yang beralamat di Jalan Pulau Madura Blahbatuh, Gianyar-Bali. Adapun bahan-bahan yang digunakan untuk analisis yaitu $\mathrm{NaOH}$ $50 \%, \mathrm{Zn}, \mathrm{HCL} 0,1 \mathrm{~N}$, aquades, pelarut n-heksana, $\mathrm{H}_{2} \mathrm{SO}_{4}$ pekat, tablet Kjeldahl, indikator phenolphthalein (PP), dan asam borat 3\%.

Alat yang digunakan untuk pembuatan kedelai terfermentasi antara lain waskom, panci, kompor gas, inkubator. Peralatan yang digunakan untuk analisis kimia adalah timbangan analitik (Shimadzu ATY224), lumpang, oven (ColeParmer), cawan porselin, alumunium foil, desikator, crus porselin, labu Erlenmeyer $250 \mathrm{ml}$ (Pyrex), alat destilasi Soxhlet (Iwaki Pyrex), pipet volume $10 \mathrm{ml}$, kertas saring biasa, benang wol, gelas ukur $100 \mathrm{ml}$ (Pyrex), gelas ukur $50 \mathrm{ml}$ (Pyrex), gelas beker $100 \mathrm{ml}$ (Pyrex), alat titrasi, muffle, hot plate, labu protein (Pyrex), labu lemak (Pyrex) dan labu Kjeldahl.

\section{Rancangan Percobaan}

Penelitian ini menggunakan rancangan acak lengkap (RAL) dengan perlakuan penambahan isolat cair yang terdiri dari 5 taraf yaitu $1 \%(\mathrm{P} 1)$, 
2\% (P2), 3\% (P3), 4\% (P4), 5\% (P5). Masingmasing perlakuan diulang sebanyak 3 kali ulangan sehingga diperoleh 15 unit percobaan. Data hasil penelitian dianalisis menggunakan analisis ragam (analysis of varian/ ANOVA) dengan menggunakan program SPSS 23. Jika perlakuan berpengaruh terhadap variabel yang diamati, maka dilanjutkan dengan Uji Jarak Berganda Duncan (Sastrosupadi,2000).

\section{Pelaksanaan Penelitian}

\section{Pembuatan isolat cair}

Isolat cair dibuat dari kedelai yang terfermentasi (sebelum ditambahkan bumbu pada proses produksi sere kedele) yang didapatkan dari produsen. Kedelai terfermentasi sebanyak 50 gram dimasukkan ke dalam erlenmeyer lalu ditambahkan dengan aquades $100 \mathrm{ml} \mathrm{1:} 2$. Kemudian dishaker sampai homogen dan disaring. Diambil bagian yang cair, cairan tersebut digunakan sebagai isolat untuk fermentasi kedelai yang menggunakan botol spray, kemudian disemprotkan dengan merata.

\section{Pembuatan kedelai terfermentasi}

Pembuatan kedelai terfermentasi meliputi persiapan bahan yaitu : sortasi dan menimbang bahan sesuai perlakuan. Kedelai yang mentah ditimbang sebanyak $150 \mathrm{~g}$ yang telah disortasi dan dicuci menggunakan air mengalir. Kemudian kedelai direndam selama 8 jam menggunakan air sebanyak 1 liter. Setelah itu kedelai direbus menggunakan air dengan perbandingan 1 bagian kedelai : 20 bagian air dengan suhu $100^{\circ} \mathrm{C}$ selama \pm 120 menit sampai matang. Kedelai yang sudah matang kemudian ditiriskan hingga tidak ada air yang menetes. Kedelai yang sudah direbus ditimbang sebanyak $300 \mathrm{~g}$ dimasukkan ke dalam wadah mangkuk. Selanjutnya kedelai ditambahkan dengan isolat cair yang sesuai persentase. Kemudian ditutup menggunakan aluminium foil dan diberikan lubang-lubang kecil, lalu difermentasi selama 24 jam, pada suhu $40^{\circ} \mathrm{C}$.

\section{Variabel yang diamati}

Variabel yang diamati dalam penelitian ini adalah kadar air dengan metode pemanasan, kadar abu dengan metode pengabuan, kadar protein dengan metode semi mikro-Kjeldahl, kadar lemak dengan metode Soxhlet, kadar karbohidrat dengan metode carbohydrate different (Sudarmadji et al., 1997), sifat sensoris menggunakan uji hedonik terhadap warna, aroma, tekstur, penerimaan keseluruhan (Soekarto, 1985), total bakteri dengan metode hitungan cawan (Fardiaz, 1992).

\section{HASIL DAN PEMBAHASAN}

Nilai rata-rata kadar air, kadar abu dan kadar protein kedelai terfermentasi dengan penambahan isolat cair dengan lama fermentasi 24 jam dapat dilihat pada Tabel 1. Kadar lemak, kadar karbohidrat, dan total bakteri disajikan pada Tabel 2 dan uji sensoris disajikan pada Tabel 3.

\section{Kadar air}

Hasil analisis ragam menunjukkan bahwa penambahan isolat cair pada kedelai berpengaruh sangat nyata $(\mathrm{P}<0,01)$ terhadap kadar air kedelai terfermentasi. Tabel 1 menunjukkan kadar air kedelai terfermentasi berkisar antara $14,10 \%$ sampai $18,13 \%$. Nilai rata-rata kadar air terendah terdapat pada penambahan isolat cair $1 \%(\mathrm{P} 1)$ yaitu sebesar $14,01 \%$, sedangkan nilai rata-rata tertinggi 
terdapat pada penambahan isolat cair 5\% (P5)

sebesar $18,13 \%$

Tabel 1. Nilai rata-rata kadar air, abu dan protein kedelai terfermentasi

\begin{tabular}{cccc}
\hline Isolat Cair & Kadar Air (\%) & Kadar Abu (\%) & Kadar Protein (\%) \\
\hline $1 \%(\mathrm{P} 1)$ & $14,10 \pm 0,07 \mathrm{~d}$ & $2,39 \pm 0,01 \mathrm{a}$ & $16,92 \pm 0,41 \mathrm{a}$ \\
$2 \%(\mathrm{P} 2)$ & $14,84 \pm 0,54 \mathrm{c}$ & $2,25 \pm 0,10 \mathrm{~b}$ & $16,63 \pm 0,39 \mathrm{a}$ \\
$3 \%(\mathrm{P} 3)$ & $15,67 \pm 0,37 \mathrm{~b}$ & $1,98 \pm 0,03 \mathrm{c}$ & $15,97 \pm 0,27 \mathrm{~b}$ \\
$4 \%(\mathrm{P} 4)$ & $17,75 \pm 0,36 \mathrm{a}$ & $1,91 \pm 0,08 \mathrm{c}$ & $14,80 \pm 0,24 \mathrm{c}$ \\
$5 \%(\mathrm{P} 5)$ & $18,13 \pm 0,28 \mathrm{a}$ & $1,87 \pm 0,08 \mathrm{c}$ & $13,76 \pm 0,25 \mathrm{~d}$ \\
\hline
\end{tabular}

Keterangan: Huruf yang sama dibelakang nilai rata-rata pada kolom yang sama menunjukkan perlakuan tidak berbeda nyata $(\mathrm{P}>0,05)$

Hal ini dapat dikatakan bahwa penambahan konsentrasi isolat pada proses fermentasi mempengaruhi kadar air kedelai terfermentasi yang dihasilkan. Kadar air yang terdapat pada kedelai terfermentasi meningkat memungkinan pertumbuhan bakteri yang dapat tumbuh dengan baik. Peningkatan kadar air juga dapat disebabkan oleh penambahan air dalam pembuatan isolat sehingga semakin banyak penambahan isolat cair maka kadar air kedelai terfermentasi meningkat.

\section{Kadar Abu}

Hasil analisis ragam menunjukkan bahwa penambahan isolat cair pada kedelai berpengaruh sangat nyata $(\mathrm{P}<0,01)$ terhadap kadar abu kedelai terfermentasi. Tabel 1 menunjukkan kadar abu kedelai terfermentasi berkisar antara 1,87\% sampai 2,39\%. Nilai rata-rata kadar abu terendah terdapat pada penambahan isolat cair 5\% (P5) yaitu sebesar $1,87 \%$ serta berbeda tidak nyata dengan perlakuan penambahan isolat cair 3\% (P3) dan 4\% (P4), sedangkan nilai rata-rata tertinggi terdapat pada penambahan isolat cair $1 \%$ (P1) sebesar 2,39\%. Hal ini menunjukkan bahwa semakin banyak penambahan isolat cair kadar abu semakin menurun.
Abu merupakan zat anorganik sisa hasil pembakaran suatu bahan makanan. Kadar abu menunjukkan total mineral yang terkandung dalam suatu bahan pangan. Semakin kecil kadar abu kedelai terfermentasi maka semakin menurun mineral yang dikandung pada kedelai terfermentasi (Ningrum,1999; Sulaswatty,2001). Semakin banyak penambahan isolat cair kadar abu kedelai terfermentasi menurun, menurunnya kadar abu dapat disebabkan aktivitas mikroba yang ada pada isolat cair dan mikroba yang ada pada isolat cair hanya memanfaatkan mineral-mineral yang terkandung dalam bahan untuk tubuh. Pada penelitian Sarkar et al.,(1998), bahwa selama proses fermentasi pada kinema terjadi penurunan sebagian besar mineral yaitu, kalsium, tembaga, besi, magnesium, mangan dan fosfor.

\section{Kadar Protein}

Hasil analisis ragam menunjukkan bahwa penambahan isolat cair pada kedelai berpengaruh sangat nyata $(\mathrm{P}<0,01)$ terhadap kadar protein kedelai terfermentasi. Tabel 1 menunjukkan kadar protein kedelai terfermentasi berkisar antara 13,7\% sampai $16,92 \%$. Nilai rata-rata kadar protein terendah terdapat pada penambahan isolat cair 5\% 
(P5) yaitu sebesar 13,7\%, sedangkan nilai rata-rata tertinggi pada penambahan isolat cair 1\% (P1) yaitu sebesar $16,92 \%$ serta berbeda tidak nyata dengan perlakuan pada penambahan isolat cair $2 \%$ (P2) yakni sebesar 16,63\%. Hal ini menunjukkan bahwa penambahan isolat cair terjadi penurunan kadar protein.

Semakin banyak penambahan isolat cair dengan lama fermentasi 24 jam kadar protein kedelai terfermentasi menurun yang dapat disebabkan oleh sejumlah protein yang ada pada isolat cair digunakan sebagai sumber nitrogen untuk pertumbuhannya dan dalam isolat cair protein yang dipecah oleh enzim proteolitik diubah menjadi asam amino dan komponen-komponen yang lebih sederhana.

\section{Kadar Lemak}

Hasil analisis ragam menunjukkan bahwa penambahan isolat cair pada kedelai berpengaruh sangat nyata $(\mathrm{P}<0,01)$ terhadap kadar lemak kedelai terfermentasi. Tabel 2 menunjukkan kadar lemak kedelai terfermentasi berkisar antara 7,42\% sampai $11,81 \%$. Nilai rata-rata kadar lemak terendah terdapat pada penambahan isolat cair 5\% (P5) yaitu sebesar 7,42\%, sedangkan nilai rata-rata tertinggi pada penambahan isolat cair 1\% (P1) yaitu sebesar $11,81 \%$ serta berbeda tidak nyata dengan perlakuan pada penambahan isolat cair $2 \%(\mathrm{P} 2)$ yakni sebesar $11,77 \%$. Hal ini menunjukkan bahwa dengan penambahan isolat cair terjadi penurunan kadar lemak.

Penurunan kadar lemak dengan semakin banyak penambahan isolat cair dapat menunjukkan bahwa mikroba dalam isolat cair mempunyai kemampuan untuk menghasilkan enzim lipase yang menghidrolisis lemak. Semakin banyak pertumbuhan bakteri pada kedelai terfermentasi maka enzim lipase akan semakin banyak sehingga lemak yang terhidrolisis semakin banyak dan menyebabkan kadar lemak menurun.

Tabel 2. Nilai rata-rata kadar lemak, karbohidrat, total bakteri kedelai terfermentasi

\begin{tabular}{cccc}
\hline Isolat Cair & Kadar Lemak (\%) & Kadar Karbohidrat (\%) & $\begin{array}{c}\text { Total bakteri } \\
\text { (log cfu/g) }\end{array}$ \\
\hline $1 \%(\mathrm{P} 1)$ & $11,81 \pm 0,48 \mathrm{a}$ & $53,52 \pm 0,95 \mathrm{c}$ & $8,73 \pm 0,02 \mathrm{c}$ \\
$2 \%(\mathrm{P} 2)$ & $11,77 \pm 0,48 \mathrm{a}$ & $55,21 \pm 0,13 \mathrm{~b}$ & $8,93 \pm 0,00 \mathrm{~b}$ \\
$3 \%(\mathrm{P} 3)$ & $10,65 \pm 0,63 \mathrm{~b}$ & $55,70 \pm 0,58 \mathrm{~b}$ & $8,94 \pm 0,00 \mathrm{~b}$ \\
$4 \%(\mathrm{P} 4)$ & $9,73 \pm 0,385 \mathrm{~b}$ & $55,74 \pm 0,30 \mathrm{~b}$ & $9,00 \pm 0,00 \mathrm{a}$ \\
$5 \%(\mathrm{P} 5)$ & $7,42 \pm 0,71 \mathrm{c}$ & $58,78 \pm 0,97 \mathrm{a}$ & $9,01 \pm 0,01 \mathrm{a}$ \\
\hline
\end{tabular}

Keterangan: Huruf yang sama dibelakang nilai rata-rata pada kolom yang sama menunjukkan perlakuan tidak berbeda nyata $(\mathrm{P}>0,05)$

\section{Kadar Karbohidrat}

Hasil analisis ragam menunjukkan bahwa penambahan isolat cair pada kedelai berpengaruh sangat nyata $(\mathrm{P}<0,01)$ terhadap kadar karbohidrat kedelai terfermentasi. Tabel 2 menunjukkan kadar karbohidrat kedelai terfermentasi berkisar antara $53,52 \%$ sampai $58,78 \%$. Nilai rata-rata kadar karbohidrat terendag terdapat pada penambahan isolat cair $1 \%$ (P1) yaitu sebesar 53,52\% sedangkan 
nilai rata-rata pada penambahan isolat cair $5 \%$ (P5) yaitu sebesar $58,78 \%$.

Hal ini menunjukkan bahwa penambahan isolat cair dengan fermentasi selama 24 jam terjadi kenaikan kadar karbohidrat. Komponen nutrisi yang dapat mempengaruhi besarnya kadar karbohidrat diantaranya kadar air, abu, protein dan lemak. Selain itu juga karbohidrat merupakan salah satu sumber energi bagi mikroba khususnya pada tahap fermentasi (Yang et al.,2011).

\section{Total Bakteri}

Hasil analisis ragam menunjukkan bahwa penambahan isolat cair berpengaruh sangat nyata $(\mathrm{P}<0,01)$ terhadap total bakteri kedelai terfermentasi. Tabel 2 menunjukkan total bakteri kedelai terfermentasi berkisar antara 8,73 log cfu/g sampai $9,01 \log \mathrm{cfu} / \mathrm{g}$. Nilai rata-rata terendah total bakteri terdapat pada penambahan isolat cair $1 \%$ (P1) yaitu sebesar 8,73 log cfu/g sedangkan nilai rata-rata tertinggi terdapat pada perlakuan penambahan isolat cair 5\% (P5) yaitu sebesar 9,01log cfu/g. Tabel 4 menunjukkan bahwa semakin banyak penambahan isolat cair total bakteri mengalami peningkatan.

Semakin banyak penambahan isolat cair maka total bakteri pada kedelai terfermentasi semakin meningkat. Meningkatnya total bakteri dapat dipengaruhi oleh kandung nutrisi pada kedelai terfermentasi sehingga pertumbuhuan bakteri menjadi optimal dan bakteri mengalami pertumbuhan berupa pertambahan jumlah sel dengan memanfaatkan nutrisi yang telah dipecah menjadi gula sederhana untuk melakukan aktivitas pertumbuhan sehingga pertumbuhan mikroba meningkat (Andarti et al., 2015).

\section{Evaluasi Sensoris}

Evaluasi sifat sensoris dilakukan dengan uji hedonik terhadap warna, aroma, tekstur dan penerimaan keseluruhan. Nilai rata-rata uji hedonik terhadap warna, aroma, tekstur dan penerimaan keseluruhan dapat dilihat pada Tabel 3.

Tabel 3. Nilai rata-rata uji hedonik warna, aroma, tekstur dan penerimaan keseluruhan kedelai terfermentasi

\begin{tabular}{|c|c|c|c|c|}
\hline \multirow[b]{2}{*}{ Isolat Cair } & \multicolumn{4}{|c|}{ Nilai Rata-rata Uji Hedonik } \\
\hline & Warna & Aroma & Tekstur & $\begin{array}{l}\text { Penerimaan } \\
\text { Keseluruhan }\end{array}$ \\
\hline $1 \%(\mathrm{P} 1)$ & $3,86 \pm 0,83 \mathrm{a}$ & $3,66 \pm 0,48 \mathrm{a}$ & $3,73 \pm 0,59 a$ & $3,66 \pm 0,61 \mathrm{a}$ \\
\hline $2 \%(\mathrm{P} 2)$ & $3,46 \pm 0,51 \mathrm{ab}$ & $3,60 \pm 0,50 \mathrm{a}$ & $3,66 \pm 0,48 \mathrm{a}$ & $3,60 \pm 0,50 \mathrm{a}$ \\
\hline $3 \%$ (P3) & $3,33 \pm 0,48 b$ & $3,60 \pm 0,50 \mathrm{a}$ & $3,60 \pm 0,50 \mathrm{a}$ & $3,53 \pm 0,51 \mathrm{a}$ \\
\hline $4 \%(\mathrm{P} 4)$ & $2,66 \pm 0,61 c$ & $3,33 \pm 0,81 \mathrm{a}$ & $3,46 \pm 0,516 a$ & $3,53 \pm 0,51 \mathrm{a}$ \\
\hline $5 \%(\mathrm{P} 5)$ & $2,86 \pm 0,51 \mathrm{c}$ & $3,26 \pm 0,70 \mathrm{a}$ & $2,46 \pm 0,51 \mathrm{a}$ & $3,40 \pm 0,63 \mathrm{a}$ \\
\hline
\end{tabular}

\section{Warna}

Hasil sidik ragam menunjukkan bahwa penambahan isolat cair pada kedelai terfermentasi berpengaruh sangat nyata $(\mathrm{P}<0,01)$ terhadap nilai rata-rata uji hedonik warna kedelai terfermentasi. 
Tabel 3 menunjukkan bahwa nilai rata-rata uji hedonik warna kedelai fermentasi berkisar antara 2,86 (biasa) sampai 3,86 (suka). Kesukaan panelis tertinggi terhadap warna pada kedelai terfermentasi pada perlakuan $1 \%$ (P1) yaitu 3,86(suka). Semakin banyak penambahan isolat cair pada kedelai terfermentasi akan berpengaruh terhadap warna, warna yang dihasilkan agak gelap.

\section{Aroma}

Hasil sidik ragam menunjukkan bahwa penambahan isolat cair pada kedelai terfermentasi tidak berpengaruh nyata $(\mathrm{P}>0,05)$ terhadap nilai rata-rata uji hedonik aroma kedelai terfermentasi. Tabel 3 menunjukkan bahwa nilai rata-rata uji hedonik aroma kedelai terfermentasi berkisar antara 3,26 (biasa) sampai 3,66 (suka). Kesukaan panelis tertinggi terhadap aroma pada kedelai terfermentasi pada perlakuan $1 \%(\mathrm{P} 1)$ yaitu 3,66 (suka).

\section{Tekstur}

Hasil sidik ragam menunjukkan bahwa penambahan isolat cair pada kedelai terfermentasi tidak berpengaruh nyata $(\mathrm{P}>0,05)$ terhadap nilai rata-rata uji hedonik tekstur kedelai terfermentasi. Tabel 3 menunjukkan bahwa nilai rata-rata uji hedonik tekstur kedelai terfermentasi berkisar antara 2,46 (biasa) sampai 3,73 (suka). Kesukaan panelis tertinggi terhadap tekstur pada kedelai terfermentasi pada perlakuan $1 \%(\mathrm{P} 1)$ yaitu 3,73 (suka).

\section{Penerimaan Keseluruhan}

Hasil sidik ragam menunjukkan bahwa penambahan isolat cair pada kedelai terfermentasi tidak berpengaruh nyata $(\mathrm{P}>0,05)$ terhadap nilai rata-rata uji hedonik penerimaan keseluruhan kedelai terfermentasi. Tabel 3 menunjukkan bahwa nilai rata-rata uji hedonik kedelai terfermentasi berkisar antara 3,40 (biasa) sampai 3,66 (suka).

\section{KESIMPULAN DAN SARAN}

\section{Kesimpulan}

Penambahan isolat cair berpengaruh sangat nyata terhadap kadar air, abu, protein, lemak, karbohidrat, total bakteri, uji hedonik warna namun tidak berpengaruh terhadap uji hedonik aroma, tekstur dan penerimaan keseluruhan.

Penambahan isolat cair 1\% menghasilkan karakteristik kedelai terfermentasi dengan karakteristik dengan kriteria : kadar air 18,13\%, kadar abu 2,39\%, kadar protein 16,92\%, kadar lemak $11,81 \%$, kadar karbohidrat $58,78 \%$, total bakteri 9,01log cfu/g, warna, aroma, tekstur, penerimaan keseluruhan suka.

\section{Saran}

Bedasarkan penelitian diatas disarankan untuk melakukan penelitian lebih lanjut mengenai jenis mikroba yang ada pada isolat tersebut dan pengaruh waktu fermentasi dalam proses pembuatan kedelai fermentasi yang dapat menghasilkan produk yang dapat diterima oleh masyarakat.

\section{DAFTAR PUSTAKA}

Andarti,I.Y., A.K.Wardani.2015. Pengaruh Lama Fermentasi Terhadap Karakteristik Kimia, Mikrobiologi, dan Organoleptik Miso Kedelai Hitam (Glyane max (L). 3(3):889-898.

Astuti, M., A. Meliala., Faabien, dan M. Wahlqvist. 2000. Review Article : Tempe, a Nutritious and 
Healthy Food from Indonesia. Asia Pacific J Clin Nutr. 9(4):322-325.

Koesoemawardani, D., N. Yuliana. 2009. Karakter Rusip dengan Penambahan Kultur Kering : Streptococcus sp. Teknologi Industri Pertanian Universitas Lampung, Lampung.

Ningrum, E.N. 1999. Pembuatan Tepung Ubi Jalar Instan Kaya Pro-vitamin. Skripsi. Fakultas Teknologi Pertanian. IPB. Bogor

Sarkar, P., E. Mprisson, U. Tinggi, S.M. Somerset dan G.S. Craven. 1998. B-Group vitamin dan mineral contents of soybeans during kinema production. J. Sci. food.Agric. $78:$ 498-502.

Sohliya, I., S. Joshi, R.K. Bhagobaty, dan R. Kumar. 2008. Tungrymbai- A Traditional Fermented Soybean Food of the Ethnic Tribes of Meghalaya. Indian Journal of Traditional Knowledge vol. 8 (4), pp 559-561

Soekarto, S.T.1985. Penilaian Organoleptik (untuk Industri Pangan dan Hasil Pertanian). Penerbit Bharata Karya Aksara, Jakarta.

Sudarmadji, S; B. Haryono dan Suhardi. 1997. Analisa Bahan Makanan dan Pertanian. Penerbit Liberty. Yogyakarta.

Sulaswatty, A., T. Idiyanti, A. Susilowati. 2001. Pemanfaatan Tepung Non Terigu Sebagai Substitusi Tepung Terigu dalam Pembuatan Cookies dan BMC. Skripsi. Fakultas Teknologi Pertanian. IPB. Bogor.

Wei, Q., W.Hall, K.C.Chang. 2001. Natto characteristics as affected by steaming time, bacillus strain, and fermentation time. Journal Food Microbiology and Safety 66(1): 167-173.

Widyantari, M.D. 2017. Inventarisasi dan Kajian Mutu Sere Kedele di Pasar Umum Kabupaten Gianyar. 2 (2) : 212-219.

Yang, H.J., S. Pak, K.R. Chung, dan D.Y. Kwon. 2011. Fermented Soybean Products and Their Bioactive Compounds. Prof. Hany El-Shemy (ed). In Tech. Crotia. 